\title{
Ecological Aspects of Urban Structure of The Pangururan District
}

\author{
Alifa Azzahra Nasution ${ }^{*}$ \\ ${ }^{1}$ Independent Researcher, Medan, Indonesia
}

\begin{abstract}
Urban structure is a city-forming arrangement that has many meanings depending on the indicators used. Ecological approach as one of the indicators is defined as a study of the spatial and temporal relationships of humans which are influenced by forces, selective, distributive, and accommodative of the environment. Pangururan district located in Samosir Regency, North Sumatra Province, Indonesia is one of the areas that is becoming the main focus of tourism development in Indonesia. This has led to the development of the city. The research was conducted using qualitative methods with data collection methods through literature studies and aerial observations. This study aims to determine how the structure of the Pangururan District is analyzed using the ecological theory of urban structure.
\end{abstract}

Keyword: ecological, urban structure, Pangururan

Received 15 September 2021 | Revised 18 October 2021 | Accepted 29 October 2021

\section{Introduction}

Cities in Indonesia continue to experience physical growth and expansion over time, not only to areas within the city but also to areas outside the city itself as a result of urban development efforts through the process of urbanizing areas around the city that are which causes spatial changes in the city and the surrounding area [1]. According to Law no. 26 of 2007 in the Indonesian context, the spatial structure is formed based on the arrangement of settlement centers and a network system of infrastructure and facilities that function as socio-economic support activities of the community which hierarchically have functional relationships [2].

Pangururan is one of the sub-districts in Samosir Regency, North Sumatra Province, Indonesia which is divided into 28 villages and 20 of them are scattered along the shores of Lake Toba. In addition, there are eight other villages located on the hill [3]. Pangururan District has a development concept that is formed naturally from time to time so that its growth does not

\footnotetext{
${ }^{*}$ Corresponding author at: J. Karya Wisata, Komp. Johor Indah Permai I Blok X No 7 Medan, Indonesia.

E-mail address: nasutionalifa@gmail.com
} 
follow regulations [4]. This study aims to determine how the structure of the Pangururan District is analyzed using the ecological theory of urban structure.

\section{Literature Review}

\section{Urban Structure}

Urban structure is a city-forming arrangement that has many meanings depending on the indicators used [5]. This indicator can be in the form of urban elements that are not visible to the eye, such as economic, social, cultural and political conditions. In addition, there are also physical elements that can be defined as road networks, city boundaries, river routes, and also areas with certain characters. These elements are defined by Kevin Lynch through the theory of Imageable City. So in short urban structure is the spatial pattern of the city that occurs due to land use [6].

The urban structure shows the use of urban space by movement and community activities by considering the physical condition of the city, so that the structure of urban space depends on physical conditions, namely land use and transportation network patterns as well as nonphysical conditions, namely movement and community activities in it [7]. There are 5 (five) categorizations of approaches to urban land use, namely the Ecological Approach, the Economic Approach, the Morphological Approach, the Activity Systems Approach, and the Factoral Ecological Approach [8].

\section{Ecological Approach}

Ecological approach is defined as a study of the spatial and temporal relationships of humans which are influenced by forces, selective, distributive, and accommodative of the environment. This approach was initiated in 1916 - 1940 by the scientific community at the Chicago School of Urban Sociology [9]. In forming a settlement, it is necessary to pay attention to several ecological elements, including climate, water sources, sunlight, and soil. Settlements always start from areas around waters, such as lakes, rivers, and the sea where water is a very important source of life for maintaining human survival [10].

Human society is organized into two levels: natural/biotic level and novel/cultural level [11]. At the natural/biotic level, the ecological processes that occur in human societies are similar to those that occur in plant/animal societies. These impersonal processes include needing a place to live, developing offspring, and needing a place to find food. This process is very clearly seen in a city through the existing social system and then produces patterns of social differentiation patterns and land use differentiation patterns. At the novel level, the interaction process that occurs is increasingly complex because humans are no longer only seen as living beings, but are seen as cultural and religious beings who have the power to create, initiate, work, which always 
develops well in relation to human relations with other humans and with the environment as well as with God [12].

\section{Concentric Zone Model}

Chicago School of Urban Sociology is interested in discussing matters concerning the nature of the cities [13]. Ernest Burgess, one of Robert Park's colleagues at the University of Chicago, in The City (1925) concluded that the intensification of industrial growth created structural stresses that caused cities to develop sequentially. This theory, known as the 'concentric zone' model, holds that cities operate in an ever-expanding fashion. When newcomers come, the old residents will move out of the core.

In this model, the least successful society at any given time will stay in or at the core. They would finally find a way out of the city core. Socially and economically, they are moving out. This process constantly drives the poor (as they improve their economic status) out of the center into more suburban areas. In the concentric theory, the area is divided into 5 zones, namely the commercial center in the city core, the transition zone in the second layer, the low class residential zone in the third layer, the middle class residential zone in the fourth layer, and the commuter zone in the outermost layer. As a simple illustration of his model, Burgess made a diagram as shown below (Figure 1).

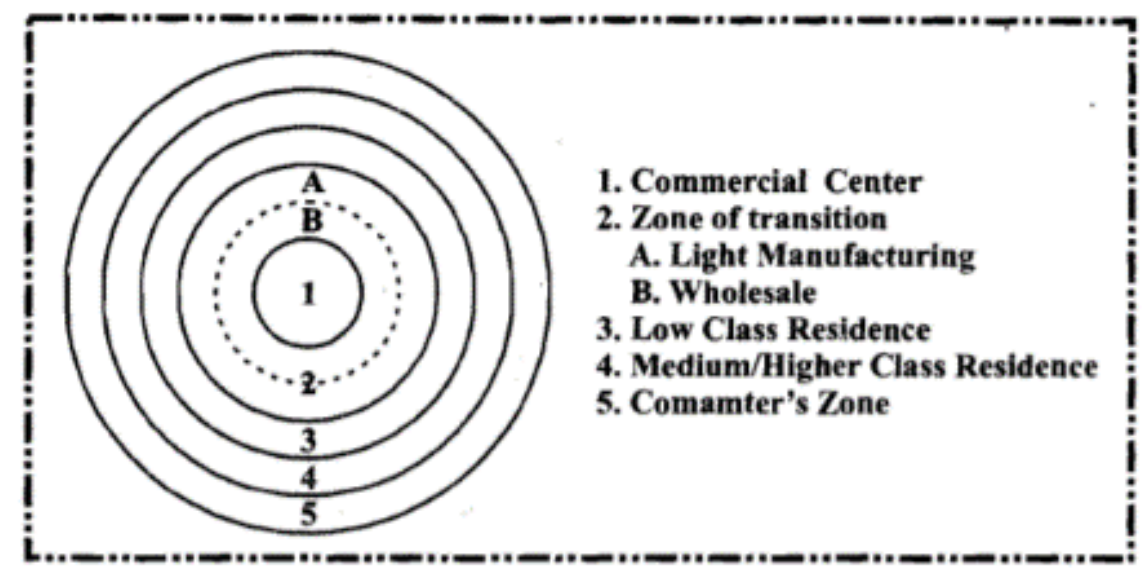

Figure 1 Concentric theory model

Burgess elaborates on this concept by noting that, during continuous movement out of the core, each zone will undergo a period of temporary equilibrium (succession) before being pushed into the outer circle by newcomers (invasion). The tendency of each inner zone to expand its territory with the subsequent invasion of the outer zone. This aspect of expansion can be called succession, a process that has been studied in detail in plant ecology [14].

Within the framework of human ecology, the social order and the physical space of the city are congruent. Although the economic system changes, spatial patterns are also thought to be maintained over time, keeping different groups of people naturally separated. From their 
perspective, social differentiation is evidence of economic progress, and spatial segregation is necessary for social progress [15].

The Chicago School understands the city as a natural space for differentiation and competition. As cities grow, and as industries compete with one another, so do workers. The occurrence of industrial competition creates the emergence of income differences which then naturally the workers will form their own community and create a new living environment in accordance with their social strata [16].

Sectors Model

Based on Homer Hoyt's 1939 study of about 140 cities in the United States, he introduced sector theory to address the discrepancy with concentric theory. This theory suggests that the development of an area will not always form a concentric circle, but will spread according to differences in its development potential. The development of an area with a sectoral type will not occur evenly in all directions. In Hoyt's sector theory, city development is influenced by road network factors or adequate accessibility such as railroads and roads. Thus a city seems to consist of each sector that is experiencing outward development. Figure 2 is a picture of urban development by sectoral type [17].

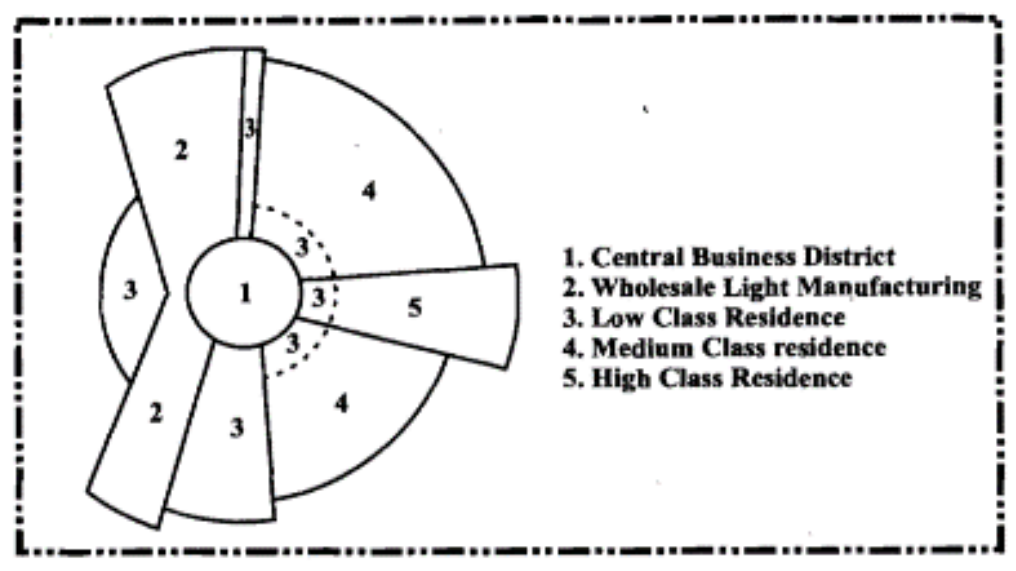

Figure 2 Sectors theory model

In figure 2 it can be seen that area 1 is the city center and the central trading district (CBD). Region 2 is a sector consisting of light industrial and large trade activities, which is located at the boundary of the city center as opposed to high quality residential areas. Region 3 shows low-class residential areas, which are located on the border of the city center with high-quality residential areas or adjacent to industrial areas. Region 4 is a middle class residential area located next to an upper class residential area. Region 5 is an upper class settlement which only covers a rather narrow sector, expansion tends to be carried out around the area [18].

Multiple Nuclei Model 
This theory is a theory formulated by C Harris and E Ullman which is known as the "multiple nuclei" theory. This pattern is basically a modification and combination of the two previous theories, the dual core theory suggests that cities are not always formed from one center, but from several other centers in one area. The location of the spatial zones formed is not determined and influenced by the distance factor from the $\mathrm{CBD}$, but is associated with a number of factors, and the influence of these factors will produce distinctive spatial patterns. Figure 3 shows a model of a city that applies the theory of multiple nuclei [18].

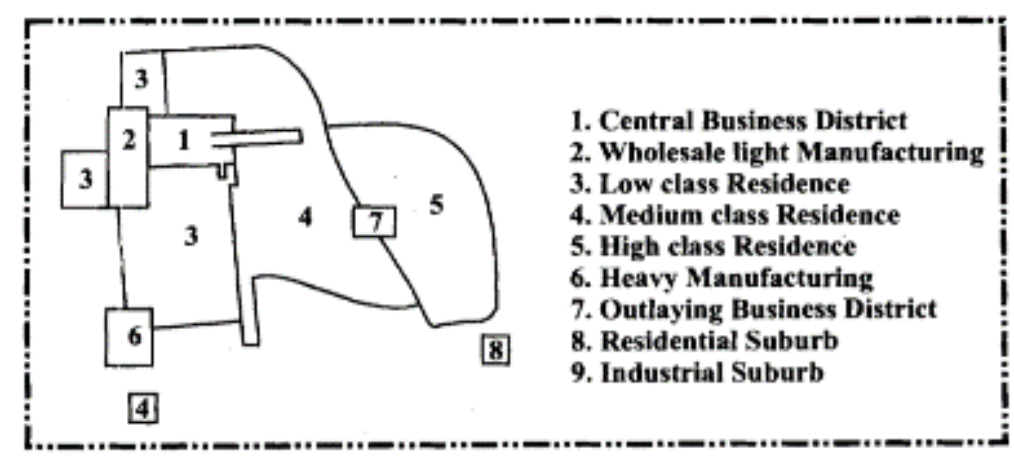

Figure 3 Multiple nuclei theory model

\section{Methodology}

The research was conducted in Pangururan District, Samosir Regency, North Sumatra Province, Indonesia. The research was conducted using qualitative methods with data collection methods through literature studies and aerial observations via the internet. The data is then analyzed based on an ecological approach to determine the shape of the urban structure pattern in the Pangururan District.

\section{$4 \quad$ Result and Discussion}

The formation of the city can not be separated from the ecological aspects and the physical form of nature. Pangururan district center is in the area around the Tano Ponggol bridge which is the link between Sumatra Island and Samosir Island. From the time of independence until the 1980s, the single most popular transit point in Samosir was Tano Ponggol, located in the Pangururan sub-district. As can be seen in figure 4, this place is located in an area that designated as a stopover for people who will carry out trading activities for agricultural products from Samosir by using vehicles via the lake, namely ships (such as ships / solu-solu passengers Tomok - Ajibata now). Apart from Tano Ponggol as a trade transit, it is also the only way of transportation out of Samosir with various destinations, most of them start their journey from the Port of Pangururan (Tajur) and Tano Ponggol. This central area can be characterized by the existence of public facilities / facilities, and city administration offices. The city center is also marked by a trading area. 


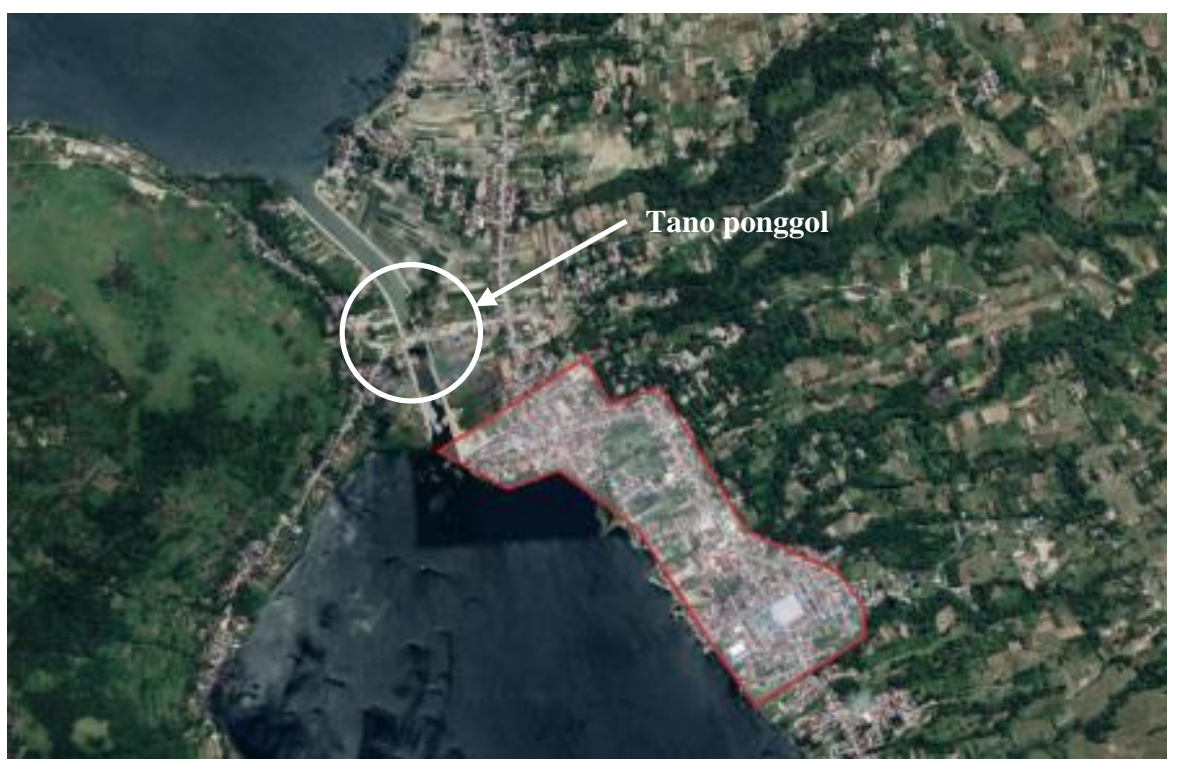

Figure 4 Pangururan district city center

From the central area, the growth of the city develops to form residential areas scattered along the waterfront of the Pangururan District. Settlements are located around water which is a source of life necessities for the community. The emergence of settlements on the edge of Pangururan waters in Samosir Regency also adjusts to the physical form of nature and culture. The relatively flat topography on the shores of the lake, with a height of $0-20 \mathrm{~m}( \pm 10 \%)$ is easier to serve as settlements and agricultural land [2].

As can be seen in figure 5, the city continues to grow north and south along the waterfront of the Pangururan District. Pangururan district is becoming increasingly developed marked by the emergence of tourist attractions. Natural tourism objects appear by taking into account the potential of the ecological aspects of Pangururan District. Hotels and inns are also increasingly popping up to accommodate the tourism needs of the Pangururan District.

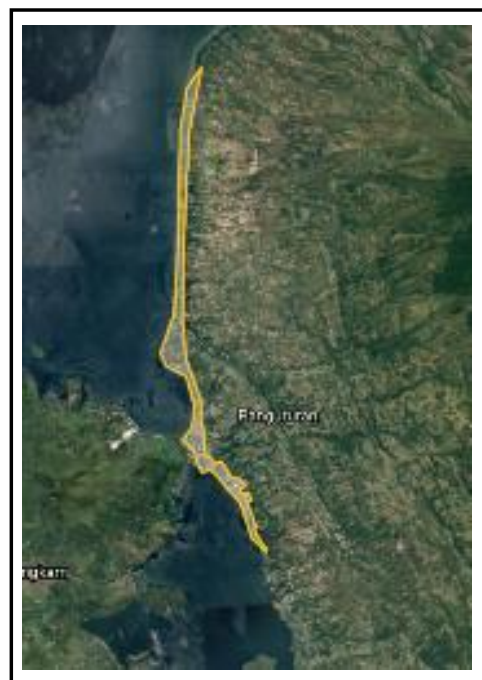

Pangururan District waterfront

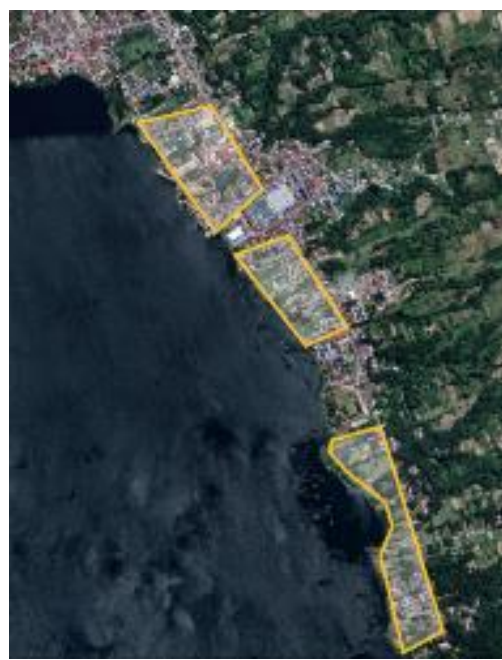

Pangururan District waterfront settlement

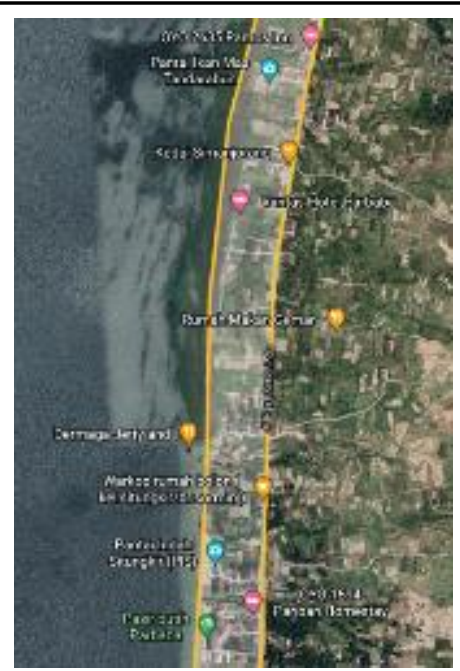

Pangururan District Waterfront attractions

Figure 5 Pangururan district waterfront function 
Moving east away from the city center it becomes increasingly difficult to find settlements and community activities. People's houses are scattered randomly and are only a few in number. In general, the people who live are people with low incomes and work as farmers.

\section{Conclusion}

The emergence and development of Pangururan district is influenced by ecological aspects and physical elements of nature. Pangururan District started from the city center near Tano Ponggol and then grew along the waterfront of Pangururan District. Judging from the shape of the urban structure based on ecological aspects, the urban structure of the Pangururan District is not in accordance with the concentric theory model where in the concentric theory it is stated that the farther away from the city center, the higher the social status of the community. Pangururan District is also not in accordance with the multiple nuclea theory model where Pangururan District itself only has one city center. So that the urban structure theory that is closest to the pattern of the Pangururan District is the sectoral theory, where the downtown area is adjacent to the trade and industrial area, and it can be seen that the residential sector and the tourist attraction sector are located along the waterfront of the Pangururan District. The geographical shape and ecological aspects of Pangururan District have the potential to form sectors with their respective main functions.

\section{REFERENCES}

[1] Simatupang, S. 2015. Eco-Imaginary: Pendekatan untuk Pengembangan Kota yang Berkelanjutan. Scale, 2(2), 262-273.

[2] Departemen Pekerjaan Umum. 2006. UU No. 26 Tahun 2007 Tentang Penataan Ruang

[3] Marpaung, B \& Senders, R. 2020. The ecological influences in forming waterfront settlements in Pangururan Sub-district, Samosir Regency. IOP Conference Series: Earth and Environmental Science. 452. 012130. 10.1088/1755-1315/452/1/012130.

[4] Marpaung, Beny \& Triska, Daniel. 2020. Study of regulation development of settlements in the edge of water in Pangururan Samosir District. IOP Conference Series: Earth and Environmental Science. 452. 012133. 10.1088/1755-1315/452/1/012133.

[5] Wibowo, A. 2014. Studi Tentang Struktur Kota Dan Sistem Transportasi Di Perkotaan Purwokerto Tahun 2013. Geo Edukasi, 3(1).

[6] Damayanti, Rully, Diktat Arsitektur Kota, Universitas Kristen Petra, Surabaya, 2008

[7] Ilma, F., \& Rakhmatulloh, A. S. 2014. Pembentukan Struktur Ruang Kompak di Kawasan Banyumanik Kota Semarang. Jurnal Pembangunan Wilayah dan Kota, 10(2), 139-152.

[8] Yunus, H. S. (2005). Struktur tata ruang kota.

[9] Burgess, Ernest W. 1967. "The Growth of the City": An Introduction to a Research Program," p. 47-62 in Robert E. Park \& Ernest W. Burgess \& Roderick D. McKenzie, 1925 (1967), The City, Chicago, II: The University of Chicago Press; reprinted from Publications of the American Sociological Boundaries. Fort Collins, CO: The Society for Human Ecology

[10] Sangalang I, Adji FF. Pengaruh kondisi hunian dan lingkungan terhadap keberlanjutan pemukiman tepi sungai. Studi kasus: Kampung Pahandut dan Desa Danau Tundai di kota Palangka Raya. Jurnal Perspektif Arsitektur. 2014 Dec;9(2).

[11] Park, R.E. Human ecology. Am. J. Sociol. 1936, 13, 1-15.

[12] Koentjaraningrat. 1980. Pengantar Imu Anthropologi. Jakarta: Aksara Baru.

[13] York, R.; Mancus, P. Critical Human Ecology: Historical Materialism and Natural Laws. Sociol. Theory 2009, 27, 122-149. 
[14] Park, R.E.; Burgess, E.W.; Janowitz, M. The City; University of Chicago Press: Chicago, IL, USA, 1925; pp. 50-51.

[15] Smith, J.L. Interpreting Neighborhood Change. Ph.D. Thesis, Cleveland State University, Cleveland, OH, USA, 1998; pp. 85-145

[16] García, I. 2019. Human ecology and its influence in urban theory and housing policy in the United States. Urban Science, 3(2), 56.

[17] Max Weber, 1905. "The City", Translated and edited by Don Martindale and Gertrud Neuwirth, new York, Free Press.

[18] Asmi, A. U., Juhadi, J., \& Indrayati, A. (2018). Fenomena Urban Sprawl Jabodetabek. Edu Geography, 6(1), 53-61. 